\title{
VENOUS CONGESTION OF THE EXTREMITIES IN RELATION TO BLOOD VOLUME DETERMINATIONS AND TO MIXING CURVES OF CARBON MONOXIDE AND T-1824 IN NORMAL HUMAN SUBJECTS ${ }^{1}$
}

\author{
By ELLEN BROWN, JAMES HOPPER, JR., JOHN J. SAMPSON, \\ AND CHARLES MUDRICK \\ (From the Dicision of Medicine, University of California School of Medicine, \\ San Francisco, California)
}

( Submitted for publication March 26, 1951 ; accepted August 20, 1951)

Investigations of circulatory problems often involve measurement of the blood volume in clinical conditions which may be characterized by important grades of stasis or venous congestion, such as pregnancy, heart failure, and shock.

As yet, no serious efforts have been made to determine the limitations of the common methods for measuring blood volume under such circumstances, although it has been claimed that delayed mixing of dyes may occur during postural stasis (1) and heart failure (2) and that serious leakage of protein-bound dyes may result from splanchnic congestion (3).

In the studies to be described, congestion was imposed on the limbs of healthy human subjects by pneumatic cuffs in such a way as to involve as much as one-fourth of the total blood volume at pressures near diastolic arterial levels. It will be shown that even such massive pooling of blood in the veins does not affect the measurement of total blood volume by a carbon monoxide method. Curves representing time-concentration relationships of carbon monoxide ( $\mathrm{CO}$ ) and the dye $T-1824$ in venous blood were only slightly modified by the presence of congestion, but showed that in the presence of massive congestion the use of sampling periods shorter than 15 to 20 minutes may lead to falsely low estimations of blood volume.

The results tend to support the modern concept, as contrasted to certain earlier, less dynamic views, concerning the nature of blood volume reservoirs $(4,5)$.

\section{METHODS}

The carbon monoxide method used has been described in detail elsewhere $(6,7)$. Essentially, it involves the in-

1 This work was supported by a grant from the Christine Breon Fund for Medical Research. troduction of a carefully measured volume of pure $\mathrm{CO}$ into a small closed system, through which the subject rebreathes for the duration of the experiment, oxygen being added as required. Samples of venous blood taken before, and at an interval of 20 minutes or longer after delivery of the gas are analyzed in triplicate for $\mathrm{CO}$ by a chemical technique utilizing palladium chloride (6).

The total CO-available volume is calculated by the iollowing formula :

$$
\frac{V_{d} \times P}{C_{f}-C_{i}} \times 100
$$

where $V_{d}$ is the apparent volume of $\mathrm{CO}$ which was delivered from the gas burette to the rebreathing system corrected to standard conditions of pressure and temperature, $\mathrm{P}$ is a correction factor for purity of the gas, and $C_{1}$ and $C_{f}$ the concentrations of $C O$ in whole venous blood samples respectively, before, and at an interval of 20 minutes (or longer) after delivery of the gas.

For each sample of blood subjected to analysis for $\mathrm{CO}$, the packed cell volume was determined, so that the total volume of erythrocytes could be calculated (see Figures 2 and 4 ). The anticoagulant was a mixture of ammonium and potassium oxalates (8). Wintrobe hematocrit tubes of $1 \mathrm{ml}$. capacity were filled in duplicate and centrifuged for 30 minutes at 3,000 r.p.m. Hematocrit values were not corrected for "trapped plasma" (9) because these experiments were concerned only with relative changes of volume, not with absolute volumes of cells or of whole blood.

By multiplying values for total $\mathrm{CO}$-available volume as obtained from analysis and the hematocrits of the corresponding blood samples, total erythrocyte volumes were calculated. The latter quantity reflects existing physiological conditions more accurately than does total $\mathrm{CO}$ available volume because it is not subject to errors of unknown magnitude which may result from differences between the hematocrit of peripheral venous blood and "total body hematocrit" at the time of sampling (10).

The major errors to be considered in using this method relate to (1) purity of the stock gas, (2) residual $\mathrm{CO}$ in the lung-rebreathing space and leakage from this system, (3) loss of $\mathrm{CO}$ to extravascular pigment stores during the interval between delivery of the gas and sampling, and (4) accuracy of chemical determination of $\mathrm{CO}$ in blood before and after delivery of the gas. 
The purity of the stock $\mathrm{CO}$ was measured by absorption with Winkler's cuprous chloride solution using a Scholander syringe, assuming the contaminating gas to be room air. Each blood volume was appropriately corrected in terms of this measurement. Suitable precautions were taken to assure airtight connections in the rebreathing system and delivery burette. No correction was made for residual $\mathrm{CO}$ in the lung-rebreathing space because errors arising from this source amount to less than 1 per cent of the final blood volume when a small rebreathing system is used (6). This is in contrast to the major errors involved with larger breathing systems (11).

It is generally accepted that estimates of absolute circulating red cell volume obtained with $\mathrm{CO}$ methods may be slightly larger than the true volumes because of CO loss to extravascular pigment stores (12). Any such losses which may be significant, however, must take place during the earliest phases of mixing because curves obtained during prolonged rebreathing show levels of $\mathrm{CO}$ in the blood which are constant within the limits of analytical error for periods of an hour or more following the initial 15 minutes of mixing $(6,7,13-15)$. Examples of such curves (see Figure 1) demonstrate the suitability of this method for long experiments of the type reported here, where relative changes, rather than absolute values for blood volume, are being studied. The $\mathrm{CO}$ methods have the unique advantage of safety when repeated measurements at frequent intervals are required, as in these experiments.

With the method used, the absolute magnitude of possible error introduced by the chemical analysis varies directly with the magnitude of the blood volume, because the quantity of gas delivered to the subject is ordinarily the same (approximately $100 \mathrm{ml}$.) in each

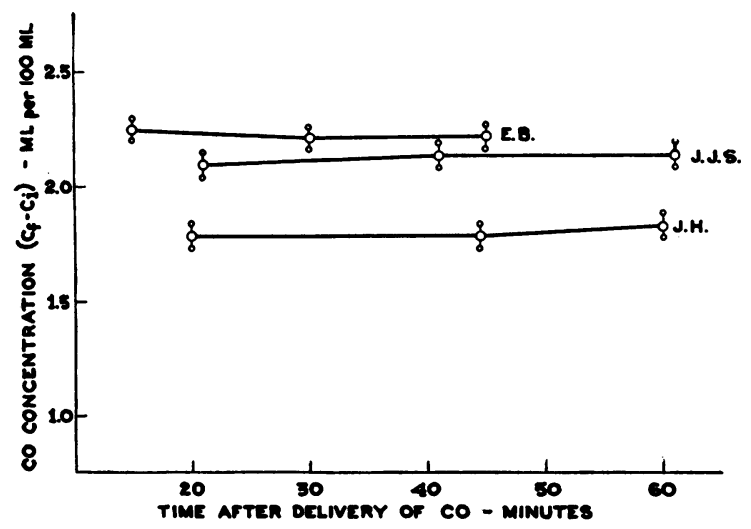

Fig. 1. Concentrations of CO in Venous Blood $\left(C_{t}-C_{1}\right)$ at Various Intervals after Introduction of the Gas during Three Experiments in Which the Subjects Were at Rest and Were Connected Continuously to the Small Rebreathing System

Small circles represent the magnitude of expected analytic error (plus and minus twice the standard error of $\left.\mathrm{C}_{1}-\mathrm{C}_{1}\right)$. experiment. In a series of 134 determinations of blood volume performed under similar conditions and by the same personnel as the experiments described here, the standard error of the difference in $\mathrm{CO}$ content between any pair of samples $\left(C_{t}-C_{1}\right)$ was found to be 0.026 volume per cent $(\tau)$. From this it may be calculated that, in terms of blood volume, 95 per cent of pairs of analyses would be expected to give values within $\pm 200 \mathrm{ml}$. of the largest blood volume $(6100 \mathrm{ml}$.) and within $\pm 130 \mathrm{ml}$. of the smallest blood volume $(3760 \mathrm{ml}$.) observed in the course of these experiments.

\section{PROCEDURES}

The subjects rested for 30 minutes in a recumbent position before any procedure was begun. Room temperature was in the neighborhood of $20^{\circ} \mathrm{C}$. and subjects were kept warm by means of blankets and electric heating pads on the feet, as required for comfort. One or, at the most, two venipunctures were sufficient for the collection of all blood samples. The 18-gauge needle inserted in an antecubital vein was kept open by means of a constant, very slow infusion of 0.9 per cent saline. Blood was allowed to flow freely through the needle for at least 15 seconds before any sample was drawn.

Venous congestion or arterial occlusion was produced by inflation of pneumatic cuffs, $15 \mathrm{~cm}$. in width, surrounding each thigh just below the groin, and a cuff, 10 $\mathrm{cm}$. in width, placed high on the left arm. The three cuffs communicated with an air reservoir so that they could be completely inflated to the desired pressures within 10 seconds.

Each of three healthy subjects, two male and one female, was subjected to the following experiments.

\section{Procedure 1}

The experiment was designed to determine whether CO-available volume is significantly smaller in the presence of massive venous congestion than following release of the obstruction. The cuffs surrounding the three limbs were first inflated to between 0 and $10 \mathrm{~mm} . \mathrm{Hg}$ below diastolic arterial pressure. After 10 minutes, a blood sample was drawn, the subject began to breathe into the closed system, and the $\mathrm{CO}$ was delivered. After $20 \mathrm{~min}$ utes of rebreathing during which congestion continued, a blood sample was drawn for determination of the COavailable volume during congestion. The cuffs were then released and blood samples drawn at approximately 10minute intervals. Rebreathing was not stopped until the last sample had been collected, 18 to 44 minutes after the cuffs were released.

\section{Procedure 2}

The purpose of this procedure was to determine whether curves representing time-concentration relationships of $\mathrm{CO}$ in venous blood might show significant differences in contour when made with congestion and without. For each subject, a pair of experiments was carried out in which $\mathrm{CO}$ concentration was determined at frequent in- 
tervals following administration of the gas; first, during venous congestion which was of similar intensity to that used in Procedure 1, and, on another day, under resting conditions. Samples of venous blood were collected at intervals of 30 to 60 seconds for the first three minutes and thereafter less frequently for a total of 20 minutes.

\section{Procedure 3}

For purposes of comparison, venous time-concentration curves were made for each subject with the dye $\mathrm{T}-1824$, but only during congestion. It was thought that similar curves made without congestion using dye would not be of sufficient value to warrant repeated injections of T-1824 into subjects often exposed to such procedures. After 10 minutes of congestion, at pressures similar to those used in Procedures 1 and 2, and while the cuffs were still inflated, $5 \mathrm{ml}$. of an 0.5 per cent solution of T-1824 were injected intravenously. Samples of venous blood were collected at intervals of 30 seconds for the first three minutes and at four, six, nine, 12, 15, and 20 minutes after delivery of the dye. Concentrations of dye in the serum were measured with the Evelyn photoelectric colorimeter (16).

\section{Procedure 4}

This was carried out in order to measure the approximate volume of blood which had been present in the congested limbs under the conditions of the foregoing experiments. The procedure was as follows: The cuffs were inflated to a pressure which was the same for each subject as that used in Procedure 1. After congestion had continued at this pressure for 10 minutes, the pressure in the cuffs was increased suddenly to $200 \mathrm{~mm}$. $\mathrm{Hg}$ or higher. A blood sample was then obtained and the $\mathrm{CO}$ delivered. After rebreathing had continued for $20 \mathrm{~min}$ utes, a sample of blood was taken for estimation of COavailable volume of the body, exclusive of those portions separated from the circulation by means of the arterial tourniquets. The cuffs were then released and rebreathing and intermittent sampling continued for periods of $61 / 2$ to 30 minutes.

\section{Procedure 5}

In order to determine the volume of blood contained in the three extremities of each subject when not congested, thus permitting calculation of the relative increase of vascular volume caused by congestion, a procedure was carried out which was identical to Procedure 4, except that arterial occlusion was not preceded by congestion.

\section{RESULTS}

\section{CO-available volume during and immediately after congestion}

Figure 2 shows the results obtained with two subjects when CO-available volume was determined during venous congestion and after release

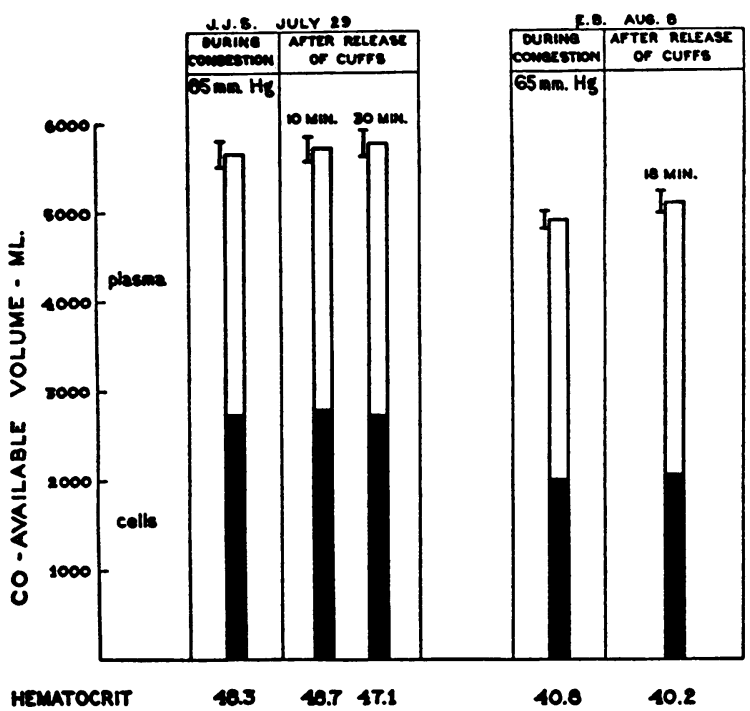

Fig. 2. CO-Available Volume, Measured during Congestion of Three Extremities by Pneumatic Cuffs, and after Release of the Cuffs, in Two SUBJECts

Cuff pressures, which are indicated at top of chart, were just below diastolic arterial pressure. Blood samples for determination of congested volume were taken 20 minutes after delivery of the gas, and after cuffs had been in place for 30 minutes. Subjects rebreathed through a closed system throughout. Here, and in Figure 4, full columns represent total $\mathrm{CO}$-available volume and shaded portions the total cell mass, calculated from hematocrits shown below. Small bars beside columns represent the range of total $\mathrm{CO}$-available volumes equivalent to plus and minus two standard errors of the $\mathrm{CO}$ concentration $\left(C_{5}-C_{1}\right)$.

of the congesting cuffs (Procedure 1). The congesting pressure used for J. J. S. was $85 \mathrm{~mm}$. Hg, and for E. B., $65 \mathrm{~mm}$. $\mathrm{Hg}$.

In both the experiments illustrated, the total erythrocyte mass measured during congestion was the same as that found after the cuffs were released. The slight increase of plasma volume which occurred in each subject following release of the cuffs, and which was reflected by a falling hematocrit, could be attributed to reabsorption of extracellular fluid which had been filtered from the capillaries of the limbs during the previous 30 minutes of massive congestion. Although for this reason total $\mathrm{CO}$-available volume tended to be slightly greater after release of the cuffs than during congestion, the difference was within the limits of error of the method, as shown by the chart. 

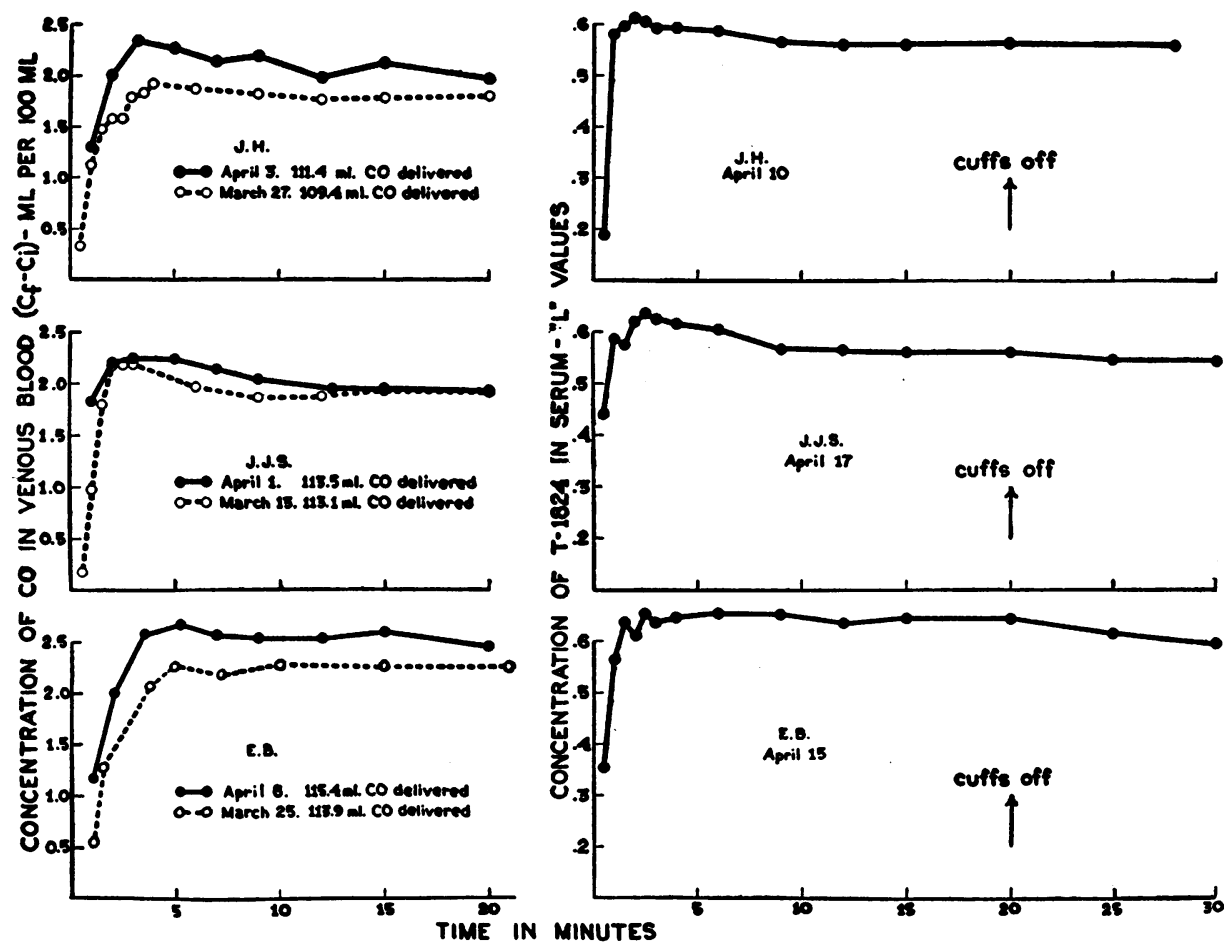

FIG. 3.

Left. Time-concentration curves of $\mathrm{CO}$ under resting conditions (open circles and dotted lines) and during congestion of three extremities (solid circles and solid lines).

Right. Time-concentration curves for T-1824 during congestion of three extremities and following release of cuffs. Dye-concentrations are expressed as the equivalent " $L$ " values (14).

\section{Time-concentration curves of $C O$ and $T-1824$ with and without congestion}

The time-concentration curves of $\mathrm{CO}$ and $\mathrm{T}$ 1824 which were obtained by Procedures 2 and 3 are shown in Figure 3. At the left side of the figure are seen the $\mathrm{CO}$ curves obtained for each subject $(a)$ during congestion of three extremities at pressures just below diastolic arterial pressure (solid circles and solid lines) and $(b)$ at a different session, without congestion (open circles and broken lines). The final concentration of $\mathrm{CO}$ after 20 minutes of rebreathing was not the same in each pair of experiments because the quantity of gas delivered was not exactly the same nor was the blood volume of each subject necessarily the same on each occasion.

All the curves, whether obtained with or without congestion, show irregularities and peaks during the first 10 minutes and become essentially flat after 15 minutes of rebreathing. In all three pairs of experiments, the curves obtained during con- gestion had more conspicuous peaks and remained higher than the final level for longer times than did the curves obtained without congestion. This is seen by direct inspection in the case of subject J. J. S. (Figure 3, center, left) where the final concentrations of $\mathrm{CO}$ happened to be the same in both experiments. It can be shown to be true also for the other two subjects where, even if corrections are made to bring the curves to the same final concentration, the curves during congestion still lie well above the curves obtained without congestion during the first 10 to 12 minutes of rebreathing.

To the right in Figure 3 are shown the timeconcentration curves for T-1824 which were made for the three subjects during congestion. In general shape, these resemble the CO curves which were made during congestion. In each instance, the concentration of the dye in venous serum became constant within 12 to 15 minutes after injection. After release of the congesting cuffs, the concentration began to diminish. 


\section{Total blood volume measured during rest and during venous congestion on different oc- casions}

Table I shows the results of measurements of the blood volume made under resting conditions and the volumes determined in the various congestion experiments described. In each case the concentration of $\mathrm{CO}$ or $\mathrm{T}-1824$ found in the blood sample taken 20 minutes after delivery of $\mathrm{CO}$ or dye was used as the basis for calculations. As would be expected from inspection of the timeconcentration curves, and from the results of the experiments in which $\mathrm{CO}$-available volume was measured during congestion and just after release of the cuffs (Procedure 1), no significant differences were seen between the results of blood volume determinations made during massive congestion and those made under similar conditions without congestion.

\section{Measurements of the volume of blood contained in the congested extremities}

It was important to determine the approximate fraction of the total blood volume which had been

TABLE I

Summary of blood volume determinations made with $C O$ and $T-1824$ under resting conditions and during congestion of three extremities by means of pneumatic cuffs

\begin{tabular}{|c|c|c|c|c|c|c|}
\hline \multirow{2}{*}{ Subject } & \multirow{2}{*}{ Date } & \multicolumn{2}{|c|}{$\begin{array}{l}\text { Apparent total } \\
\text { blood volume* }\end{array}$} & \multirow{2}{*}{$\begin{array}{c}\text { Cuff } \\
\text { pressure }\end{array}$} & \multirow{2}{*}{$\begin{array}{l}\text { Indi- } \\
\text { cator }\end{array}$} & \multirow{2}{*}{$\underset{\text { crit }}{\text { Hemato }}$} \\
\hline & & $\begin{array}{l}\text { Uncon- } \\
\text { gested }\end{array}$ & $\begin{array}{l}\text { Con- } \\
\text { gested }\end{array}$ & & & \\
\hline J. J. S. & $\begin{array}{lr}\text { Feb. } & 5 \\
\text { Mar. } & 13 \\
\text { Apr. } & 1 \\
\text { Jul. } & 29 \\
\text { Apr. } & 17\end{array}$ & $\begin{array}{c}m l . \\
5,360 \\
5,880\end{array}$ & $\begin{array}{c}m l . \\
5,880 \\
5,650 \\
5,830\end{array}$ & $\begin{array}{c}m m . H g \\
\\
60 \\
85 \\
60\end{array}$ & $\begin{array}{c}\mathrm{CO} \\
\mathrm{CO} \\
\mathrm{CO} \\
\mathrm{CO} \\
\mathrm{T}-1824\end{array}$ & $\begin{array}{l}\mathrm{ml.l} \\
100 \mathrm{ml} . \\
45.5 \\
45.5 \\
45.45 \\
48.3 \\
44.6\end{array}$ \\
\hline J. H. & $\begin{array}{l}\text { Feb. } 20 \\
\text { Mar. } 27 \\
\text { Apr. } 22 \\
\text { Apr. } 3 \\
\text { Apr. } 10\end{array}$ & $\begin{array}{l}5,060 \\
6,100 \\
5,740\end{array}$ & $\begin{array}{l}5,640 \\
5,670\end{array}$ & $\begin{array}{l}70 \\
75\end{array}$ & $\begin{array}{c}\mathrm{CO} \\
\mathrm{CO} \\
\mathrm{CO} \\
\mathrm{CO} \\
\mathrm{T}-1824\end{array}$ & $\begin{array}{l}46.55 \\
45.6 \\
45.55 \\
42.25 \\
43.35\end{array}$ \\
\hline E. B. & $\begin{array}{lr}\text { Dec. } & 3 \\
\text { Mar. } & 25 \\
\text { Apr. } 8 \\
\text { Aug. } 8 \\
\text { Apr. } 15\end{array}$ & $\begin{array}{l}4,800 \\
5,040\end{array}$ & $\begin{array}{l}4,710 \\
4,900 \\
4,590\end{array}$ & $\begin{array}{l}70 \\
65 \\
64\end{array}$ & $\begin{array}{c}\text { CO } \\
\text { CO } \\
\text { CO } \\
\text { CO } \\
\mathrm{T}-1824\end{array}$ & $\begin{array}{l}38.6 \\
39.3 \\
39.55 \\
40.8 \\
39.15\end{array}$ \\
\hline
\end{tabular}

* Based on blood samples taken 20 minutes after delivery of the indicator.

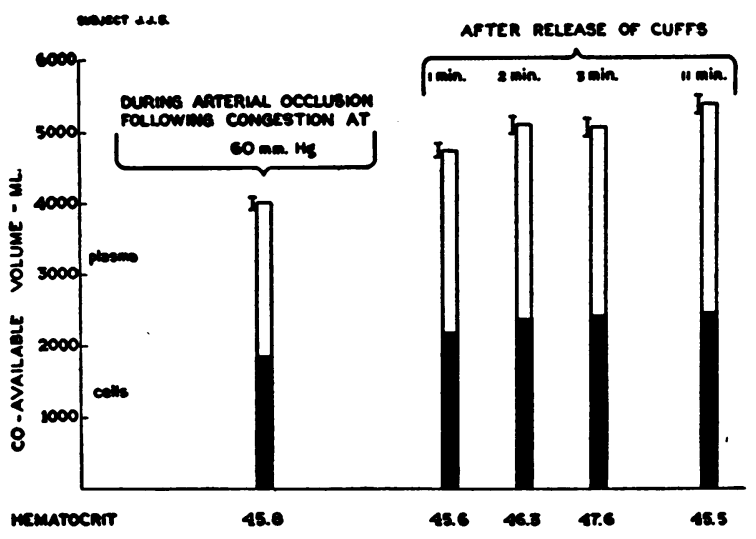

Fig. 4. CO-Available Volume Measured during a Single Experiment While the Circulation to Both legs and One ArM Was Occluded by Cuffs INFlated to 200 MM. Hg, following 10 Minutes of Congestion at Cuff Pressures of $60 \mathrm{MM}$. Hg (First Column) and at One, Two, Three and 11 Minutes after Release of TOURniguets (LAst Four Columns)

Subject was connected to rebreathing system throughout. (Data are represented as in Figure 2.)

contained in the congested extremities of each subject during the experiments described. Figure 4 illustrates the results of a typical experiment employing Procedure 4. The first column shows total CO-available volume and total erythrocyte volume while the congested extremities were excluded from the circulation by means of arterial tourniquets. Columns 2, 3, 4, and 5 show the changes in $\mathrm{CO}$-available volume after release of the occluding and congesting cuffs. At the time of the final sampling, 11 minutes after release of the cuffs, an increase of $1370 \mathrm{ml}$. had occurred in CO-available volume, and of $610 \mathrm{ml}$. in total erythrocyte volume, amounting to increases of 25 per cent in both total volume and erythrocyte volume. Results of the three experiments carried out in this fashion are summarized in Table II. The increases of volume following release of arterial tourniquets were between 20 and 28 per cent of the final CO-available volumes; in other words, between one-fifth and one-fourth of the total blood volume of each subject was involved in the three congested limbs.

In each of the three experiments, release of the tourniquets and return of the previously pooled blood to more active circulation resulted in transient severe hyperpnea, a further evidence of the extent to which venous return from the limbs had 
TABLE II

Increases of total CO-available volume and of erythrocyte volume, compared with final volumes after release of arterial tourniguets

\begin{tabular}{|c|c|c|c|c|c|c|c|}
\hline \multirow{2}{*}{ Subject } & \multicolumn{2}{|c|}{$\begin{array}{c}\text { Increase of volume } 6 / \text { to } 11 \\
\text { minutes after release of } \\
\text { occluding cuffs }\end{array}$} & \multicolumn{2}{|c|}{$\begin{array}{c}\text { Final volume } 6 / \text { to } 11 \\
\text { minutes after release of } \\
\text { occluding cuffs }\end{array}$} & \multicolumn{2}{|c|}{$\begin{array}{l}\text { Percentage increase after } \\
\text { release of cuffs }\end{array}$} & \multirow{2}{*}{$\begin{array}{c}\text { Congesting } \\
\text { pressure } \\
\text { prior to } \\
\text { occlusion } \\
(m m . H g)\end{array}$} \\
\hline & $\begin{array}{l}\text { Total } \\
(m l .)\end{array}$ & $\begin{array}{l}\text { Cells } \\
(m ! .)\end{array}$ & $\begin{array}{l}\text { Total } \\
(\mathrm{ml} .)\end{array}$ & $\begin{array}{l}\text { Cells } \\
(\mathrm{ml.})\end{array}$ & $\begin{array}{l}\text { Total } \\
(\%)\end{array}$ & $\begin{array}{l}\text { Cells } \\
(\%)\end{array}$ & \\
\hline
\end{tabular}

Procedure 4-Limbs congested by pneumatic cuffs for 10 minutes before application of tourniquet pressure

\begin{tabular}{l|r|l|l|l|l|l|l|l}
\hline J. J. S. & 1,370 & 610 & 5,370 & 2,440 & 25.5 & 25.0 & 60 \\
J..H. & 1,630 & 820 & 5,880 & 2,820 & 27.8 & 29.1 & 75 \\
E. B. & 920 & 420 & 4,680 & 1,870 & 19.7 & 22.5 & 65 \\
\hline
\end{tabular}

Procedure 5-No congestion prior to application of tourniquet pressure

\begin{tabular}{l|l|l|l|l|l|l|l|l}
\hline J. J.S. & 630 & 310 & 5,320 & 2,590 & 11.8 & 12.0 & 0 \\
J. H. & 900 & 440 & 5,740 & 2,700 & 15.7 & 16.3 & 0 \\
E. B. & 720 & 260 & 4,360 & 1,800 & 16.5 & 14.4 & 0 \\
\hline
\end{tabular}

been impeded by the congesting cuffs. Similar hyperpnea did not follow release of the tourniquets in the experiments where arterial occlusion was not preceded by congestion (Procedure 5).

Comparison of the results obtained by Procedure 4 with those of Procedure 5, in which the volume of blood in the limbs was estimated without congestion, showed that, for each subject, the blood content of the extremities had been approximately doubled by congestion (see Table II).

\section{DISCUSSION}

The congestion which was imposed on the limbs in these experiments was made as extensive and as severe as possible, in order that circulatory stasis as it occurs clinically might be matched or exceeded. The experimental conditions could not simulate exactly the disturbances of blood distribution which may occur in heart failure, pregnancy, or shock for several reasons. First, the total blood volume of the healthy subjects was not increased, as it may be in congestive failure and pregnancy. Second, the experimental congestion was local and confined to the limbs rather than general and including the splanchnic and pulmonary circuits. Third, the pressure imposed on the veins of the experimental subjects was much higher than is ordinarily found clinically. Thus, whereas the total area of distribution of the congested regions might have been smaller, and the total volume of blood involved less, the intensity of the congesting pressure was considerably greater in the experimental situation than in any of the clinical states under consideration.

The results of experiments designed to measure the vascular volume of the limbs (Procedures 4 and 5) showed that a large fraction of the circulatory volume, in the ne ghborhood of one-fifth to one-fourth of the total blood volume, was contained in the congested regions under the conditions of the experiments. Further, it was shown that the vascular volume of the three extremities of each subject was approximately doubled by congestion. These estimates of volume, with and without congestion, are in surprisingly close agreement with results of similar studies made by others using slightly different techniques $(11,17)$. Use of a closed rebreathing system and of $\mathrm{CO}$ permitted measurement of blood volume while the tourniquets were in place and at intervals after release during a single experimental session. In the earlier studies in which the dye T-1824 was used, it was necessary to make determinations of blood volume, first with the circulation intact, and again, on another day, with arterial tourniquets in place (17).

It is probable that in all of these experiments involving arterial tourniquets, pressures distal to the occluding cuffs were slightly raised during the period of complete occlusion. For this reason, the grade of congestion which was present during measurement of vascular volume by means of Procedure 4 might have been somewhat higher 
than that which existed during Procedures 1, 2, and 3 , but the difference was presumably slight (18). It is certain that the rate of blood flow through the congested extremities was greatly diminished at the same time that the volume of blood contained in them was approximately doubled. Information is lacking on which to base an exact quantitative estimate of the decrement in flow (19).

It seems reasonable to conclude that the conditions of the experiments were sufficiently severe with respect to the volume of blood involved and the degree of obstruction to venous outflow, to permit critical testing of methods for measuring blood volume in clinical conditions characterized by massive pooling of blood.

The results of Procedures 1 and 2 have proved that the mixing period of 20 minutes which is usually employed with the $\mathrm{CO}$ method is more than sufficient for complete equilibration between the inspired gas and the entire volume of blood, even when a considerable portion of the circulating blood is moving at reduced speed in regions of congestion. Observations made with the dye T-1824 were somewhat less complete (Procedure 3 , Table I), but these also support the conclusion that with sampling periods of 15 minutes or longer, and using either $\mathrm{CO}$ or dye, the total blood volume, and not merely the fraction of the blood which is circulating most rapidly, is reached by the indicator. These observations are in agreement with conclusions drawn from earlier experiments (20), in which the dye concentrations of venous bloods from upper and lower extremities were compared at various times after injection of dye during quiet standing and during recumbency.

At the time this series of experiments was being planned, it was thought that the time-concentration curves for $\mathrm{CO}$ and $\mathrm{T}-1824$ which were made while the limbs were congested might prove to have distinctive contours as compared with curves made when congestion was not present (20-22). If this were the case, venous mixing curves might prove to have clinical value as a means of discovering the presence of vascular pools in regions where detection by more direct means is difficult, such as in the pelvic circulation during pregnancy. It was found, however, that the curves made with and without congestion were essentially the same in contour, even though in each pair of curves the one made during congestion had a slightly higher initial peak than the one made under resting conditions. Clearly, the presence of regional or general venous congestion could not be suspected, nor could any estimate concerning the relative magnitudes of "effective" versus total blood volume be made by simple inspection of individual mixing curves such as this if obtained under uncontrolled clinical conditions.

Conclusions are not justified here concerning the validity of plasma volume determinations made with T-1824 during limb congestion, because of the small number of experiments carried out with this substance. Difficulties have been encountered in using this method for studies of exercise (23) and shock where it became necessary to make indirect calculations of dye loss because of capillary leakage during the sampling period (24). When capillary pressure is greatly increased in the limbs, and probably to an even greater extent when visceral engorgement exists, the rates of loss of both fluid and protein from the blood stream are increased and the rate of lymphatic return uncertain $(3,25,26)$. Under such circumstances, methods depending on labelling of erythrocytes have the advantage that total circulating red cell volume can be determined directly.

The results reported in this paper, together with a number of other observations $(4,20,27-30)$ are in conflict with certain views which were expressed in the early literature on blood volume, concerning the nature of blood reservoirs (5). The brilliant studies of Barcroft on the functions of the spleen in animals (31) and certain studies by Wollheim on man $(32 \mathrm{a}, \mathrm{b}, \mathrm{c})$ provided a basis for the concept that important fractions of the blood, disproportionately rich in erythrocytes, could be sequestered in such depots as the spleen and the subpapillary venous plexus of the skin, where they might remain relatively static until returned to active circulation.

Barcroft's observations apparently do not apply to the spleen of normal man $(4,28-30)$. Wollheim was led by his experimental results to the conclusion that total blood volume, including both cell and plasma fractions, was diminished by several hundred milliliters during congestion which was similar in extent and intensity to that used in our experiments $(32 a, b, c)$. However, it can 
be shown that the apparently conflicting results of the earlier studies were subject to a systematic error brought about by the use of premature sampling.

At the time Wollheim's studies were made, information was lacking concerning the time required for complete mixing of dyes in the blood stream. Inspection of the mixing curves obtained in the present study (Figure 3 ) demonstrates that at the sampling time used by Wollheim (three to six minutes), all of the curves were passing through their maxima, the peaks for the "congested" curves being higher than for the "uncongested" ones. Calculations based on samples taken at these time intervals after injection of the dye would lead to estimates of volume which are smaller than the true volume, and the error in this direction would be greater when congestion is present than under resting conditions.

It is possible to calculate, for each subject used in the present series, the apparent blood volume that would be obtained from the concentration of $\mathrm{CO}$ found in a five-minute and a 20 -minute sample, with and without congestion, using the data from which Figure 3 was constructed. The data and results of these calculations appear in Table III and provide quantitative evidence concerning the magnitude of error which is introduced by premature sampling, both with congestion and without. The error in the direction of too small a CO-available volume is about twice as great (as much as $790 \mathrm{ml}$.) if the limbs are congested as that if there is no congestion (as much as 260 ml.). Examination of the time-concentration curves for T-1824 (Figure 3, right) shows that similar errors may be expected from premature sampling when this dye is used.

Although the results reported here are directly applicable only to the circulation in the extremities, they lend support to a relatively dynamic concept of blood volume reservoirs, in which these are regarded as regions of the circulation which are capable of accepting large volumes of blood, and through which blood of normal concentration continues to flow at varying rates. The relative accessibility of blood pooled in the limbs has been demonstrated by the marked similarities in shape between the time-concentration curves of $\mathrm{CO}$ made with and without congestion. Alterations in the dynamics of mixing were manifested only by the slight differences in contour appearing during the first 15 minutes after introduction of the gas. Thus, it is found that when sampling is delayed for at least 15 minutes after introduction of the indicator, total erythrocyte volume, whether measured with $\mathrm{CO}(27)$, as was done here, or indirectly by means of dyes (20), appears to be the same, with or without congestion. Total blood volume and plasma volume are smaller if measured during congestion only by the small fraction of plasma fluid which may be lost through filtration, while venous and capillary pressures are elevated during congestion (Figure 2) (20, 2527).

It may be concluded that the presence of massive venous congestion does not cause delay in mixing of $\mathrm{CO}$ or of dyes to an extent which is sufficient to interfere with determinations of blood volume, provided blood samples are taken after an interval of not less than 15 minutes following

TABLE III

Comparisons between apparent CO-available volumes obtained from blood samples taken five minutes and 20 minutes after delivery of $\mathrm{CO}$, under resting conditions and during congestion

\begin{tabular}{|c|c|c|c|c|c|c|c|}
\hline \multirow{2}{*}{ Subject } & \multirow{2}{*}{ Experiment } & \multirow{2}{*}{$\begin{array}{l}\text { Volume of } \mathrm{CO} \\
\text { delivered }\end{array}$} & \multicolumn{2}{|c|}{$c_{i}-C_{i}$} & \multicolumn{2}{|c|}{$\begin{array}{c}\text { Calculated CO-available } \\
\text { volume }\end{array}$} & \multirow{2}{*}{$\begin{array}{l}\text { Difference between } \\
\text { result based on } \\
5 \mathrm{~min} \text {. and on } \\
20 \mathrm{~min} \text {. sample }\end{array}$} \\
\hline & & & $5 \mathrm{~min}$. & $20 \mathrm{~min}$. & $5 \mathrm{~min}$. & $20 \mathrm{~min}$. & \\
\hline J. J.S. & $\begin{array}{l}\text { Without congestion } \\
\text { With congestion }\end{array}$ & $\begin{array}{c}m l . \\
113.1 \\
113.5\end{array}$ & $\begin{array}{c}m l . / 100 \mathrm{ml} . \\
2.05 \\
2.23\end{array}$ & $\begin{array}{c}m l . / 100 \mathrm{ml} . \\
1.92 \\
1.93\end{array}$ & $\begin{array}{c}m l . \\
5,520 \\
5,090\end{array}$ & $\begin{array}{c}m l . \\
5,880 \\
5,880\end{array}$ & $\begin{array}{c}m l . \\
-360 \\
-790\end{array}$ \\
\hline J. H. & $\begin{array}{l}\text { Without congestion } \\
\text { With congestion }\end{array}$ & $\begin{array}{l}109.4 \\
111.4\end{array}$ & $\begin{array}{l}1.89 \\
2.25\end{array}$ & $\begin{array}{l}1.80 \\
1.97\end{array}$ & $\begin{array}{l}5,800 \\
4,950\end{array}$ & $\begin{array}{l}6,090 \\
5,650\end{array}$ & $\begin{array}{l}-290 \\
-700\end{array}$ \\
\hline E. B. & $\begin{array}{l}\text { Without congestion } \\
\text { With congestion }\end{array}$ & $\begin{array}{l}113.9 \\
115.4\end{array}$ & $\begin{array}{l}2.26 \\
2.66\end{array}$ & $\begin{array}{l}2.26 \\
2.45\end{array}$ & $\begin{array}{l}5,030 \\
4,350\end{array}$ & $\begin{array}{l}5,030 \\
4,710\end{array}$ & $\begin{array}{r}0 \\
-260\end{array}$ \\
\hline
\end{tabular}


delivery of the indicator. Under such circumstances, total, rather than merely "effective," blood volume is measured.

\section{SUM MARY}

1. The blood volume of three healthy human subjects was measured by a $\mathrm{CO}$ method involving a closed rebreathing system (a) under resting conditions, and $(b)$ during and after release of venous congestion of three extremities produced by pneumatic cuffs inflated to pressures just below the diastolic level.

2. Time-concentration curves for venous blood were made, using $\mathrm{CO}$ under resting conditions and $\mathrm{CO}$ and $\mathrm{T}-1824$ during venous congestion.

3. The volume of blood contained in the congested extremities was measured and found to be in the neighborhood of one-fifth to one-fourth of total blood volume.

4. It was found that when a mixing time of 20 minutes or longer is allowed after delivery of the gas, CO-available volume is the same, whether or not venous congestion of the extremities is present.

5. Congestion of the extremities was found to produce consistent, slight changes in contour of time-concentration curves for $\mathrm{CO}$, particularly during the earliest phases of mixing. These changes in contour were not sufficiently striking to permit use of such curves for estimating the presence or degree of venous pooling. Because of the characteristics of the curves, the use of sampling periods shorter than 15 minutes may cause errors in the direction of falsely low blood volumes.

6. It is concluded that the presence of massive congestion of the extremities does not interfere with complete admixture of $\mathrm{CO}$ or $\mathrm{T}-1824$ with the entire blood volume within 20 minutes, and that with the $\mathrm{CO}$ method employed, total, rather than only "effective," blood volume is measured.

7. The results have been discussed in relation to some concepts concerning the nature of blood volume reservoirs.

\section{REFERENCES}

1. Linhard, J., A dye-method for determining the blood volume in man. Am. J. Physiol., 1926, 77, 669.

2. Gibson, J. G., 2nd, and Evans, W. A., Jr., Clinical studies of the blood volume. I. Clinical applica- tion of a method employing the azo dye "Evans Blue" and the spectrophotometer. J. Clin. Invest., 1937, 16, 301.

3. Peters, J. P., The role of sodium in the production of edema. New England J. Med., 1948, 239, 353.

4. Ebert, R. V., and Stead, E. A., Jr., Demonstration that in normal man no reserves of blood are mobilized by exercise, epinephrine, and hemorrhage. Am. J. M. Sc., 1941, 201, 655.

5. McDowall, R. J. S., The Control of the Circulation of the Blood. Longmans, Green \& Co., New York, 1938.

6a. Hopper, J., Jr., Tabor, H., and Winkler, A. W., Simultaneous measurements of blood volume in man and dog by means of Evans blue dye, T-1824, and by means of carbon monoxide. I. Normal subjects. J. Clin. Invest., 1944, 23, 628.

b. Hopper, J., Jr., Winkler, A. W., and Elkinton, J. R., Simultaneous measurements of blood volume in man and dog by means of Evans blue dye, T-1824, and by means of carbon monoxide. II. Under abnormal conditions, including secondary shock. J. Clin. Invest., 1944, 23, 636.

7. Mudrick, C., Hopper, J., Jr., Brown, E., and Talbot, J. C., In preparation.

8. Heller, V. G., and Paul, H., Changes in cell volume produced by varying concentrations of different anticoagulants. J. Lab. \& Clin. Med., 1933-34, 19, 777.

9. Chapin, M. A., and Ross, J. F., The determination of the true cell volume by dye dilution, by protein dilution, and with radioactive iron. The error of the centrifuge hematocrit. Am. J. Physiol., 1942, $137,447$.

10. Gibson, J. G., 2nd, Peacock, W. C., Seligman, A. M., and Sack, T., Circulating red cell volume measured simultaneously by the radioactive iron and dye methods. J. Clin. Invest., 1946, 25, 838.

11. Asmussen, E., On determination of blood volume by carbon monoxide method. Acta physiol. Scandinav., 1942, 3, 156.

12. Root, W. S., Roughton, F. J. W., and Gregersen, M. I., Simultaneous determinations of blood volume by $\mathrm{CO}$ and dye (T-1824) under various conditions. Am. J. Physiol., 1946, 146, 739.

13. Chang, H. C., and Harrop, G. A., Jr., The determination of the circulating blood volume with carbon monoxide. J. Clin. Invest., 1928, 5, 393.

14. Killick, E. M., The nature of the acclimatization occurring during repeated exposure of the human subject to atmospheres containing low concentrations of carbon monoxide. J. Physiol., 1948, 107, 27.

15. Courtice, F. C., and Gunton, R. W., The determination of the blood volume in man by the carbon monoxide and dye methods. J. Physiol., 1949, 108, 142. 
16. Gibson, J. G., 2nd, and Evelyn, K. A., Clinical Studies of the blood volume. IV. Adaptation of the method to the photoelectric microcolorimeter. J. Clin. Invest., 1938, 17, 153.

17. Ebert, R. V., and Stead, E. A., Jr., The effect of the application of tourniquets on the hemodynamics of the circulation. J. Clin. Invest., 1940, 19, 561.

18. Wilkins, R. W., and Bradley, S. E., Changes in arterial and venous blood pressure and flow distal to a cuff inflated on the human arm. Am. J. Physiol., 1946, 147, 260.

19. Friedland, C. K., Hunt, J. S., and Wilkins, R. W., Effects of changes in venous pressure upon blood flow in the limbs. Am. Heart J., 1943, 25, 631.

20. Thompson, W. O., Thompson, P. K., and Dailey, M. E., The effect of posture upon the composition and volume of the blood in man. J. Clin. Invest., 1927-28, 5, 573.

21. Nylin, G., and Pannier, R., L'influence de l'orthostatisme et du shock sur la vitesse circulatoire déterminée à l'aide du phosphore radioactif. ·Arch. Int. Pharm. et Thér., 1947, 73, 401.

22. Nylin, G., The dilution curve of activity of arterial blood after intravenous injection of labeled corpuscles. Am. Heart J., 1945, 30, 1.

23. Ebert, R. V., and Stead, E. A., Jr., An error in measuring changes in plasma volume after exercise. Proc. Soc. Exper. Biol. \& Med., 1941, 46, 139.

24. Noble, R. P., and Gregersen, M. I., Blood volume in clinical shock. I. Mixing time and disappearance rate of T-1824 in normal subjects and in patients in shock; determination of plasma volume in man from 10-minute sample. J. Clin. Invest., 1946, $25,158$.

25. Landis, E. M., and Gibbon, J. H., Jr., The effects of temperature and of tissue pressure on the movement of fluid through the human capillary wall. J. Clin. Invest., 1933, 12, 105.

26. Landis, E. M., Jonas, L., Angevine, M., and Erb, W., The passage of fluid and protein through the human capillary wall during venous congestion. J. Clin. Invest., 1932, 11, 717.

27. Waterfield, R. L., The effects of posture on the circulating blood volume. J. Physiol., 1931, 72, 110.

28. Yang, C. S., and Chang, $H$. C., The effect of adrenaline on the circulating blood volume in individuals with normal and enlarged spleens and after splenectomy. Chinese J. Physiol., 1930, 4, 21.

29. Nylin, G., The effect of heavy muscular work on the volume of circulating red corpuscles in man. Am. J. Physiol., 1947, 149, 180.

30. Nylin, G., The effect of adrenalin injected intravenously on the volume of circulating erythrocytes. Acta cardiologica, 1946, 1, 225.

31. Barcroft, J., Recent knowledge of the spleen. Lancet, $1925,1,319$.

32a. Wollheim, E., Die Bestimmung der zirkulierenden Blutmenge. Ztschr. f. klin. Med., 1928, 108, 463.

b. Wollheim, E., Zur funktionellen Bedeutung der Cyanose. Ztschr. f. klin. Med., 1928, 108, 248.

c. Wollheim, E., Zur Funktion der subpapillären Gefässplexus in der Haut. Klin. Wchnschr., 1927, 6, 2134. 